\title{
Trans rectal ultra sound guided prostate biopsies: a single centre experience in Sri Lanka
}

\author{
M D S Lokuhetty ${ }^{1}$, H D Wijesinghe ${ }^{2}$, D T Abeysuriya ${ }^{3}$, U C Samarasinghe ${ }^{4}$ and N D Perera ${ }^{5}$
}

(Index words: carcinoma prostate, prostate biopsy, Sri Lanka, serum PSA)

\begin{abstract}
Background Trans rectal ultrasound guided prostate biopsy (TRUS) was introduced to Sri Lanka in 2002.

Objectives 1 . To study clinicopathological features of males subjected to TRUS biopsy 2. To compare estimation of tumour burden by two methods in carcinoma prostate $(\mathrm{CaP})$.

Methods 749 symptomatic males subjected to TRUS biopsy over 64 months at a single centre. Information was retrieved from case records. Tumour burden in CaP was calculated as: 1. Calculated tumour burden (CTB) total percentage tumour in each core/total number of cores 2. Percentage positive biopsy cores (PPBC) number of positive cores / total number of cores $X 100$. SPSS 15.0, student's t test and Spearman's rank correlation coefficients were used for statistical analysis.

Results $35.2 \%$ had CaP, microacinar in type. $34.88 \%$ were poorly differentiated. CaP was frequent among older patients $(P<0.00001)$. The prostate volume in $\mathrm{CaP}$ was significantly lower than in the benign group $(P<0.05)$. Prostate specific antigen (PSA) level was significantly higher in $\mathrm{CaP}(\mathrm{P}<0.00001)$. A 99.6\% sensitivity and 4.7\%
\end{abstract}

specificity was observed at PSA of $4 \mathrm{ng} / \mathrm{ml}$ for detecting CaP. Specificity was $98 \%$ at $25.5 \mathrm{ng} / \mathrm{ml}$, with a sensitivity of $44.4 \%$. CTB and PPBC had similar correlations with biochemical/histological parameters of $\mathrm{CaP}$ and were strongly correlated (0.786).

Interpretation Males with $\mathrm{CaP}$ were older, had higher PSA levels and smaller prostates. A cut off level of PSA $>4 \mathrm{ng} / \mathrm{ml}$ could be used for directing symptomatic patients for TRUS biopsy to detect $\mathrm{CaP}$, keeping in mind that specificity is $98 \%$ only at $25.5 \mathrm{ng} / \mathrm{ml}$. Both CTB and PPBC could be used to calculate tumour burden in TRUS with CaP.

\section{Introduction}

Carcinoma prostate $(\mathrm{CaP})$ accounted for $4.9 \%$ (301 cases) of all cancers affecting Sri Lankan men in 2005 [1]. Trans rectal ultrasound guided core biopsy of the prostate (TRUS biopsy), is considered a safe and accurate diagnostic test for $\mathrm{CaP}$ [2]. This study aims to document our experience with 749 TRUS biopsies in symptomatic men, since introduction of the technique to Sri Lanka in September 2002.

${ }^{1,2,3}$ Department of Pathology, Faculty of Medicine, University of Colombo, ${ }^{4}$ Nawaloka Hospital, Colombo and ${ }^{5}$ National Hospital of Sri Lanka.

Correspondence: HDW, e-mail: <harshima@hotmail.com>. Received 25 July and revised version accepted 11 December 2008. Competing interests: none declared. 


\section{Objectives}

1. To study clinicopathological features of symptomatic men subjected to TRUS biopsy of prostate, with a view to formulate future diagnostic strategies for $\mathrm{CaP}$.

2. To compare estimation of tumour burden by calculated tumor burden (CTB) and percentage positive biopsy core (PPBC) methods in diagnosed $\mathrm{CaP}$.

\section{Materials and methods}

749 TRUS biopsies performed over a period of 64 months at a single tertiary care hospital in the private sector were included in the study. All these men presented with lower urinary tract symptoms with or without abnormal digital rectal examination (DRE) findings. DRE and ultrasound examination of the prostate followed by biopsies, were performed by a single radiologist using an $18 \mathrm{G}$ needle. A minimum of 6 tissue cores were obtained from right and left sides of the base, middle and the apical regions of the prostate. Additional cores were obtained from nodules, if present.

The age and serum PSA (obtained prior to DRE and ultrasonography) were retrieved from case records. The prostate volume was obtained from documented ultrasonography findings. Prostate specific antigen density (PSAD) was calculated by dividing the serum PSA in $\mathrm{ng} / \mathrm{ml}$ by the volume of prostate in milliliters. Hematoxylin and eosin stained slides were examined by a single pathologist and categorised as follows 1. Benign with/ without inflammation 2. CaP (acinar/ductal) and atypical glands suspicious, but not diagnostic of carcinoma. $\mathrm{CaP}$ were graded and scored based on the Gleason scoring system [3].

The tumour burden was calculated as:

Calculated tumor burden (CTB)

Percentage positive biopsy cores (PPBC)

$=$ Number of positive tissue cores $\times 100$

Total number of tissue cores

Presence of high-grade prostatic intra epithelial neoplasia (PIN) and perineural invasion were documented. SPSS 15.0 software was used for analysis. Student's t test was used to compare means and Spearman's rank correlation coefficients were used to assess correlations.

\section{Results}

$264(35.2 \%)$ were diagnosed to have $\mathrm{CaP}$ on TRUS biopsy. $454(60.6 \%)$ were diagnosed as benign. Small acini that were suspicious but not diagnostic of carcinoma were seen in 31 cases $(4.2 \%)$. The age of the study population ranged from 33-90 years with a mean age of 69.3 years $(\mathrm{SD}=8.2$ years). The mean age of men with $\mathrm{CaP}$ was 71.3 years $(\mathrm{SD}=7.8$ years). The mean age of those diagnosed as benign was 68.1 years ( $\mathrm{SD}=8.2$ years). Older men had malignant disease more often than younger men $(\mathrm{P}<0.00001)$ (Figure 1).

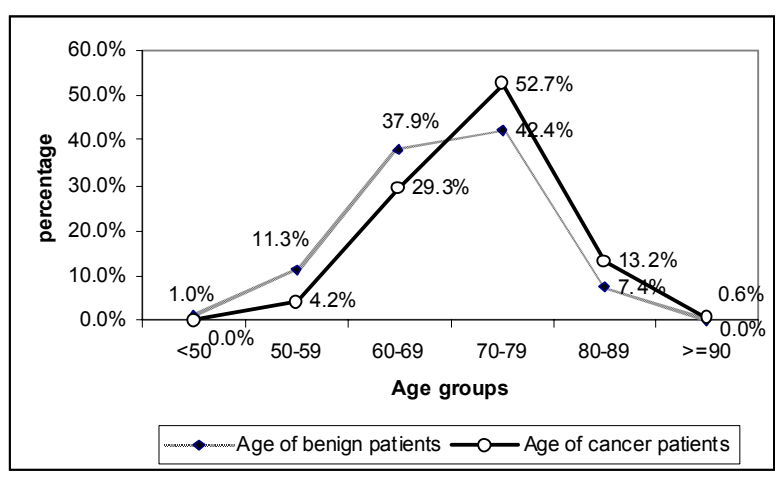

Figure 1. Distribution of patients with benign and malignant diagnosis according to age

Serum PSA was measured in 716 men (Table 1). The mean serum PSA was $51.2 \mathrm{ng} / \mathrm{ml}(\mathrm{SD}=80.0 \mathrm{ng} / \mathrm{ml})$ in men with diagnosed CaP. It was $20.1 \mathrm{ng} / \mathrm{ml}(\mathrm{SD}=31.1 \mathrm{ng} / \mathrm{ml})$ in the benign group (Table 2). This difference was statistically significant $(\mathrm{P}<0.00001)$. When the receiver operating curve (ROC curve) was applied, a sensitivity of $99.6 \%$ and a specificity of $4.7 \%$ were seen at a serum PSA level of $4 \mathrm{ng} / \mathrm{ml}$ in detecting CaP. A specificity of $98 \%$ was observed only at serum PSA of $25.5 \mathrm{ng} / \mathrm{ml}$, however with a low sensitivity (44.4\%). Application of recommended age specific PSA cut off values [4] showed no change in sensitivity and no significant increase in specificity as compared to a cut off serum PSA of $4 \mathrm{ng} / \mathrm{ml}$. The mean Serum PSA Density (PSAD) for the $\mathrm{CaP}$ and the benign groups were $1.3 \mathrm{ng} / \mathrm{ml}^{2}\left(\mathrm{SD}=1.8 \mathrm{ng} / \mathrm{ml}^{2}\right)$ and $0.56 \mathrm{ng} / \mathrm{ml}^{2}$ $\left(\mathrm{SD}=2.1 \mathrm{ng} / \mathrm{ml}^{2}\right)$ respectively. This difference was not statistically significant $(\mathrm{p}>0.05)$. The mean prostate volume was $41.6 \mathrm{ml}(\mathrm{SD}=26.8 \mathrm{ml})$ in the $\mathrm{CaP}$ group. The non-cancer group had a mean prostate volume of $52.3 \mathrm{ml}(\mathrm{SD}=32.8$ $\mathrm{ml})$. This difference was statistically significant $(\mathrm{P}<0.001)$.

$\mathrm{CaP}$ was small acinar in type in 99.2\% (262/264). An additional large duct component was present in two. The combined Gleason score of CaP group is shown in table 3. Majority (60/172-34.88\%) had poorly differentiated carcinomas with a Gleason score of 8 to 10 . There was a trend for increasing levels of serum PSA and PSAD with higher Gleason scores (Table 3). High grade prostatic intraepithelial neoplasia (PIN) was seen in a man, associated with a moderately to poorly differentiated adenocarcinoma of small acinar type. Perineural invasion was present in $19(7.1 \%$ - 19/264) men with CaP. There was 
no association between perineural invasion and the Gleason's score $(\mathrm{P}>0.05)$.

Spearman's rank correlation coefficients for associations of PPBC and CTB with the biochemical and histological parameters are shown in Table 4. None of the differences of correlations between CTB and PPBC were statistically significant (Table 4). However, a strong correlation of 0.780 was noted between PPBC and CTB.

Table 1. Serum PSA levels in relation to histological diagnosis

\begin{tabular}{lcccc}
\hline & $<4 \mathrm{ng} / \mathrm{ml}$ & $4.1-10 \mathrm{ng} / \mathrm{ml}$ & $>10.1 \mathrm{ng} / \mathrm{ml}$ & Total number \\
\hline Benign & 21 & 137 & 275 & 433 \\
Malignant & 1 & 55 & 196 & 252 \\
Benign with suspicious foci & 1 & 12 & $\mathbf{4 8 9}$ & 31 \\
Total & $\mathbf{2 3}$ & $\mathbf{2 0 4}$ & $\mathbf{7 1 6}$ \\
\hline
\end{tabular}

Table 2. Means of PSA, PSAD and prostate volume in relation to histological diagnosis

\begin{tabular}{llcc}
\hline & $\begin{array}{c}\text { Mean serum } \\
P S A(\mathrm{ng} / \mathrm{ml})\end{array}$ & $\begin{array}{c}\text { Mean } \\
\left(\mathrm{ng} / \mathrm{ml}^{2}\right)\end{array}$ & $\begin{array}{c}\text { PSAD prostate volume } \\
(\mathrm{ml})\end{array}$ \\
\hline Benign & $20.17(\mathrm{SD}=31.15)$ & $0.56(\mathrm{SD}=2.12)$ & $52.36(\mathrm{SD}=32.87)$ \\
Malignant & $51.22(\mathrm{SD}=80.01)$ & $1.31(\mathrm{SD}=1.87)$ & $44.54(\mathrm{SD}=55.97)$ \\
Benign with suspicious foci & $27.75(\mathrm{SD}=64.28)$ & $0.5(\mathrm{SD}=1.02)$ & $56.04(\mathrm{SD}=29.98)$ \\
\hline
\end{tabular}

Table 3. Distribution of the combined Gleason's score in patients with CaP and its association with serum PSA and PSAD

\begin{tabular}{clcccc}
\hline $\begin{array}{c}\text { Combined } \\
\text { Gleason's Score }\end{array}$ & Differentiation & $\begin{array}{c}\text { Number of } \\
\text { patients }\end{array}$ & $\begin{array}{c}\text { Percentage } \\
\%\end{array}$ & $\begin{array}{c}\text { Mean } \\
\text { PSA }\end{array}$ & $\begin{array}{c}\text { Mean } \\
\text { PSAD }\end{array}$ \\
\hline $2-5$ & Well & 2 & 1.16 & 24.17 & 1.06 \\
6 & Moderately & 58 & 33.72 & 24.58 & 0.76 \\
7 & Moderately to poorly & 52 & 30.23 & 55.99 & 1.29 \\
$8-10$ & Poorly & 60 & 34.88 & 88.99 & 2.14 \\
Total & & $\mathbf{1 7 2}$ & $\mathbf{1 0 0 . 0 0}$ & & \\
\hline
\end{tabular}

Table 4. Spearman's rank correlation coefficients for association of PPBC and CTB with biochemical and histological parameters of $\mathrm{CaP}$

\begin{tabular}{llcl}
\hline & PPBC & $\begin{array}{c}\text { Calculated tumor } \\
\text { burden }(\text { CTB })\end{array}$ & $\begin{array}{c}\text { Difference between the } \\
\text { two correlations }\end{array}$ \\
\hline PSA level & $0.398(\mathrm{p}<0.01)$ & $0.245(\mathrm{p}<0.01)$ & Not significant \\
PSA density & $0.435(\mathrm{p}<0.01)$ & $0.329(\mathrm{p}<0.01)$ & Not significant \\
Combined Gleason's score & $0.400(\mathrm{p}<0.01)$ & $0.295(\mathrm{p}<0.01)$ & Not significant \\
Perineural invasion & $-0.176(\mathrm{p}<0.01)$ & $-0.175(\mathrm{p}<0.05)$ & Not significant \\
\hline
\end{tabular}




\section{Discussion}

The prevalence of $\mathrm{CaP}$ in this TRUS guided biopsy series is $35.2 \%$. Brawer et al reported a prevalence of $30.5 \%$ for $\mathrm{CaP}$ in 187 TRUS biopsies of men who had PSA levels greater than $4.0 \mathrm{ng} / \mathrm{ml}$ [5]. The prevalence observed in this study is slightly higher.

Mean PSA level of men with CaP was significantly higher than those with benign disease. The mean prostate volume in patients with $\mathrm{CaP}$ was significantly lower than in the benign group; however the difference between the mean PSAD values of the two groups was not statistically significant. These observations can be explained by current knowledge that malignant prostate epithelial cells are capable of producing more PSA per gram of tissue than normal or hyperplastic cells [6]. It also confirms that PSAD is not reliable for exclusion of a man with high PSA from biopsy.

A sensitivity of $99.6 \%$ for $\mathrm{CaP}$ detection was obtained at a cut off serum PSA level of $4 \mathrm{ng} / \mathrm{ml}$. Therefore it is desirable that all symptomatic men with serum PSA levels above $4 \mathrm{ng} / \mathrm{ml}$ are directed towards further investigations including TRUS biopsy. However, it should be borne in mind that the specificity for $\mathrm{CaP}$ is only $4.7 \%$ at this level of serum PSA. As the specificity for $\mathrm{CaP}$ increases with rising serum PSA $(36.8 \%$ at PSA $10.05 \mathrm{ng} / \mathrm{ml}$ and $98 \%$ at PSA of $25.5 \mathrm{ng} / \mathrm{ml}$ ) a raised level of PSA especially above $25.5 \mathrm{ng} / \mathrm{ml}$ makes a symptomatic man more likely to have $\mathrm{CaP}$. It is documented that most men with slightly elevated PSA levels (4-10 ng/ml) do not have carcinoma [7]. Our observations were similar.

The pathology of $\mathrm{CaP}$ in Sri Lanka is hitherto not documented. $99.2 \%$ of the $\mathrm{CaP}$ in this series was of small acinar type. The majority were poorly differentiated with a combined Gleason score of 8-10. High grade PIN was detected in one case in association with $\mathrm{CaP}$. None had high grade PIN in the absence of carcinoma. Documented incidence for high grade PIN in TRUS is 4.6\% [8]. However, in these countries serum PSA is used as a screening tool for $\mathrm{CaP}$ in asymptomatic men [9]. Therefore it is likely that men with pre-invasive stage of disease (high grade PIN) are detected more often than in our setting.

Recent studies show that both the number of cores positive for cancer and the total percentage of core length involved by cancer independently predict extra capsular extension and positive surgical margins [10]. This information obtained by TRUS biopsies play a critical role in patient management. Having calculated the burden of tumour in the study sample by two different methods, PPBC showed a higher correlation with the PSA level, PSA density and combined Gleason's score when compared with CTB. The difference in correlations by the two methods however were not significant. In view of the strong correlation observed between them, it is possible to use both PPBC and CTB to calculate tumour burden in TRUS biopsies. However, calculation of CTB is time consuming and laborious, where as $\mathrm{PPBC}$ is more user-friendly. $\mathrm{PPBC}$ was shown to be related to the preoperative serum PSA level, Gleason score, clinical stage, extra-prostatic disease, seminal vesicle involvement and to have a relationship with biological outcome after radical prostatectomy [11]. Similarly PPBC was related to the serum PSA level and the Gleason score in this study. Although radical prostatectomy is still not widely performed in Sri Lanka, it is offered more often in therapeutic protocols of localized $\mathrm{CaP}$. Therefore, the results of this study on tumour burden on TRUS biopsies will be useful when CaP diagnosed on TRUS biopsy are directed to curative surgery.

\section{Acknowledgements}

We gratefully acknowledge the contributions made by Prof Rajitha Wickremasinghe of the University of Kelaniya, who guided us in the statistical analysis of data and all surgical colleagues who referred symptomatic men for TRUS biopsy.

\section{References}

1. National Cancer Control Programme. Cancer Registry: Cancer Incidence in Sri Lanka 2005.

2. Lippman HR, Ghiatas AA, Sarosdy MF. Systematic transrectal ultrasound guided prostate biopsy after negative digitally directed prostate biopsy. Journal of Urology 1992; 147: $827-9$.

3. Bostwick DG. Grading prostate cancer. American Journal of Clinical Pathology 1994; 102: S38-56.

4. Watson E, Jenkins L, Bukach C, Austoker J. The PSA test and prostate cancer: information for primary care. NHS Cancer Screening Programmes, Sheffield: 2002.

5. Brawer MK, Chetner MP, Beatie J. Screening for prostate carcinoma with prostate specific antigen. Journal of Urology 1992; 147: 841-5.

6. Stamey TA. Diagnosis of prostate cancer: a personal view. Journal of Urology 1992; 147: 830-2.

7. Magi-Galluzi C, Epstein JI. Threshold for diagnosing prostate cancer over time. Human Pathology 2003; 34: 1116-8.

8. Egan AJM, Bostwick DG. Prediction of extraprostatic extension of prostate cancer based on needle biopsy findings: perineural invasion lacks significance on multivariate analysis. American Journal of Surgical Pathology 1997; 21: 1496-500.

9. Smith RA, Cokkinides V, Eyre HJ. American Cancer Society Guidelines for the Early Detection of Cancer, 2005. CA A Cancer Journal for Clinicians 2005; 55: 31-44.

10. Zhou M, Epstein JI. The reporting of prostate cancer on needle biopsy; prognostic and therapeutic implications and the utility of diagnostic markers. Pathology 2003; 35: 472-9.

11. Antunes AA, Srougi M, Dall'Oglio MF, Crippa A, Campagnari JC, et al. The percentage of positive biopsy cores as a predictor of disease recurrence in patients with prostate cancer treated with radical prostatectomy. British Journal of Urology International 2005; 96: 1258-63. 